\title{
PENGARUH TERAPI MURROTAL TERHADAP KUALITAS TIDUR PASIEN POST OP MASTEKTOMI DI RUMAH SAKIT UMUM DAERAH Dr. H. ABDOEL MOELOEK PROVINSI LAMPUNG
}

\author{
Tari Monica Josephianney ${ }^{1}$ \\ ${ }^{1}$ RSUD Abdoel Moeloek \\ Email: tarimonicaj@gmail.com
}

\begin{abstract}
THE INFLUENCE OF QORAN RECITING THERAPY TO POST MASTECTOMY-SURGERY PATIENT'S SLEEP QUALITY IN DR. H. ABDUL MOELOEK PUBLIC HOSPITAL IN LAMPUNG PROVINCE
\end{abstract}

Introduction: Advance stadium breast cancer patient management has worse prognosis that early stadium breast cancer, even the surgery procedure cannot recover the patient because cancer has spread into important organs. In general, the breast cancer management is divided into two: local therapy and systemic therapy (chemotherapy, hormonal therapy, and marrow bone replacement. The objective of local therapy is to remove local cancer including conservative surgery (lumpectomy and radiation therapy), modified mastectomy, and mastectomy with reconstruction. The objective of this research was to find out the influence of Qoran reciting therapy to post-mastectomy-surgery patient's sleep quality in Dr. H. Abdul Moeloek public hospital in Lampung province in 2019.

Method: this was a quantitative research with quasi experiment approach. Population was 40 patients with breast cancer who received mastectomy procedure in Dr. H. Abdul Moeloek public hospital from 2018 to March 2019. Samples were of total population.

Result: The mean value of post-mastectomy surgery patient's sleeping quality before Qoran reciting therapy was 32.40 with lowest and highest values were 6 and 49 respectively. The mean value of post-mastectomy surgery patient's sleeping quality after Qoran reciting therapy was 21.03 with lowest and highest values were 5 and 32 respectively.

Conclusion: The statistic test result with t-test derived $p$-value $0.000<0.05$, and it was concluded that there was an influence of Qoran reciting therapy to postmastectomy-surgery patient's sleep quality in Dr. H. Abdul Moeloek public hospital in Lampung province in 2019. The researcher expects that respondents implement Qoran reciting therapy in their homes, so that their sleep qualities improve.

Keywords: Qoran Reciting Therapy \& Sleep Quality 


\section{INTISARI : PENGARUH TERAPI MURROTAL TERHADAP KUALITAS TIDUR PASIEN POST OP MASTEKTOMI DI RUMAH SAKIT UMUM DAERAH Dr. H. ABDOEL MOELOEK PROVINSI LAMPUNG}

Pendahuluan : Penatalaksanaan pada pasien kanker payudara dengan stadium lanjut memiliki prognosis yang lebih buruk dibandingkan dengan kanker payudara stadium dini, bahkan tindakan operatif pun tidak dapat menyembuhkannya karena kanker sudah mengalami penyebaran ke organ-organ penting. Secara garis besar, penatalaksanaan kanker payudara dibagi menjadi dua, yaitu terapi lokal dan terapi sistemik (kemoterapi, terapi hormonal, dan penggantian sumsum tulang). Terapi lokal bertujuan untuk menyingkirkan adanya kanker local yang meliputi bedah konservatif (lumpectomy dan terapi radiasi), mastektomi yang dimodifikasi, serta mastektomi dengan rekontruksi. Tujuan: tujuan penelitian diketahui pengaruh terapi murottal terhadap kualitas tidur pasien post op mastektomi di RSUD dr. H. Abdoel Moeloek Provinsi Lampung Tahun 2019.

Metode : Jenis penelitian kuantitatif. Rancangan analisis menggunakan pendekatan quasi eksperimen. Populasi dalam penelitian ini adalah semua pasien kanker payudara dengan mastektomi tahun 2018 sampai dengan Maret tahun 2019 di RSUD dr. H. Abdoel Moeloek Provinsi Lampung berjumlah 40 pasien, Sampel minimum yang didapatkan berjumlah 40 responden. Penelitian ini menggunakan teknik sampling total populasi.

Hasil : Diketahui bahwa nilai rata-rata (mean) kualitas tidur pasien post operasi mastektomi sebelum diberikan terapi murottal al-qur'an adalah 32,40 dengan nilai terendah 6 dan nilai tertinggi 49 dan nilai rata-rata (mean) kualitas tidur pasien post operasi mastektomi sesudah diberikan terapi murottal al-qur'an adalah 21,03 dengan nilai terendah 5 dan nilai tertinggi 32 .

Kesimpulan : Berdasarkan uji statistik, Uji T di dapatkan p-value 0,000, atau $p$ value $<$ 0,05 maka dapat disimpulkan bahwa terdapat pengaruh terapi murottal terhadap kualitas tidur pasien post operasi mastektomi di RSUD dr. H. Abdoel Moeloek Provinsi Lampung Tahun 2019. Diharapkan dengan hasil penelitian ini responden dapat menerapkan terapi murottal Al-qur'an dirumah, sehingga dengan terapi murottal maka kualitas tidur pasien post op dapat teratasi dengan baik.

Kata Kunci: Terapi Murottal Al-qur'an, Kualitas Tidur, Mastektomi

\section{PENDAHULUAN}

Kanker payudara merupakan ancaman serius yang menakutkan bagi kaum perempuan. Kanker payudara termasuk jenis penyakit ganas yang sangat ditakuti oleh kaum perempuan, kanker payudara menempati urutan kedua setelah leher rahim. Di Indonesia, problem kanker payudara menjadi lebih besar lagi karena lebih dari $70 \%$ penderita datang ke dokter pada stadium lebih besar lagi. Oleh karena itu, permasalahan kanker payudara membutuhkan perhatian khusus, baik dari kaum perempuan sendiri (sebagai manusia yang rentan terserang kanker tersebut) maupun seluruh lapisan masyarakat (Putra, 2015)

Berdasarkan data World Health Organization (WHO) penyakit kanker merupakan penyebab kematian terbanyak di dunia, dimana kanker sebagai penyebab kematian nomor 2 di dunia sebesar 13\% setelah penyakit kardiovaskular. Kanker payudara merupakan kanker kedua penyebab kematian tertinggi pada wanita didunia. Berdasarkan data International Agency for Research on Cancer (IARC) tahun 2012, perkiraan 
jumlah kasus baru kanker payudara sekitar 1,67 juta (25\% dari semua kanker) dan mengalami peningkatan $13,75 \%$ dari tahun 2008 (WHO, 2017).

Di Indonesia, prevalensi penyakit kanker juga cukup tinggi. Berdasarkan data Riset Kesehatan Dasar (Riskesdas) tahun 2013, prevalensi tumor/ kanker di Indonesia adalah 1,4 per 1000 penduduk, atau sekitar 330.000 orang. Kanker tertinggi di Indonesia pada perempuan adalah kanker payudara dan kanker leher rahim. Berdasarkan data Sistem Informasi Rumah Sakit 2010, kasus rawat inap kanker payudara 12.014 kasus $(28,7 \%)$, kanker leher rahim 5.349 kasus (12,8\%) (Riskesdas, 2013).

Menurut Data Dinas Kesehatan Provinsi Lampung, pada tahun 2014 angka kejadian kanker payudara mencapai 230 kasus dan pada tahun 2015 mengalami peningkatan yang cukup signifikan hingga mencapai 276 kasus. Angka kejadian kanker payudara paling tinggi ada pada Kota Bandar Lampung yang mencapai hingga mencapai 26 kasus dan yang terendah ada Di Kota Metro yang hanya mencapai 7 kasus. Dari data tersebut didapatkan bahwa sasaran kanker payudara mayoritas adalah remaja putri (Dinkes Provinsi Lampung, 2015).

Untuk mendeteksi adanya kanker payudara dapat dilakukan dengan (SADARI) Pemeriksaan Payudara Sendiri. Tindakan ini sangat penting karena hampir $85 \%$ benjolan di payudara ditemukan oleh penderita sendiri. Pada wanita normal, American cancer society menganjurkan wanita berusia diatas 20 tahun untuk melakukan SADARI, karena diusia mulai dari 20 tahan mempunyai risiko terbesar mengalami kanker payudara. Setiap satu bulan, usia 35-40 tahun melakukan mamografi, diatas 40 tahun melakukan check up pada dokter ahli, lebih dari 50 tahun check up rutin dan mamografi setiap tahun, dan wanita yang berisiko tinggi pemeriksaan dokter lebih serin dan rutin. Tujuan dari program deteksi dini kanker payudara yaitu untuk menurunkan angka kematian pada penderita, karena kanker yang diketemukan pada stadium awal tentu memberikan harapan hidup lebih lama daripada apabila diketemukan pada stadium lanjut (Mulyani, 2013).

Penatalaksanaan pada pasien kanker payudara dengan stadium lanjut memiliki prognosis yang lebih buruk dibandingkan dengan kanker payudara stadium dini, bahkan tindakan operatif pun tidak dapat menyembuhkannya karena kanker sudah mengalami penyebaran ke organ-organ penting. Secara garis besar, penatalaksanaan kanker payudara dibagi menjadi dua, yaitu terapi lokal dan terapi sistemik (kemoterapi, terapi hormonal, dan penggantian sumsum tulang). Terapi lokal bertujuan untuk menyingkirkan adanya kanker local yang meliputi bedah konservatif (lumpectomy dan terapi radiasi), mastektomi yang dimodifikasi, serta mastektomi dengan rekontruksi (Solehati \& Kosasih, 2015).

Menurut Akman et al. (2015), gangguan tidur diketahui mempengaruhi kualitas hidup dan psikologis penderita kanker. Gangguan tidur seperti nyeri dapat membangunkan seseorang dari tidur biasanya, mencegah untuk tertidur, dan berkontribusi terhadap hilangnya energi atau kelelahan. Kelelahan sendiri dapat mengakibatkan tidur pada siang hari dan terjadi interupsi tidur pada malam hari (Alifiyanti,dkk, 2017).

Pada penelitian yang dilakukan Devita, Yanti, Dyah (2017), tentang kualitas tidur pasien kanker payudara berdasarkan terapi yang 
diberikan di RSUP Dr. Hasan Sadikin Bandung didapatkan hasil pada jenis terapi pengobatan kanker payudara yang dijalani oleh responden, bahwa semua terapi pengobatan kanker menyebabkan kualitas tidur yang buruk. Pada sebagian besar responden dengan single mastektomi, yaitu 5 dari 11 responden mengalami gangguan tidur pada komponen latensi $>60$ menit. Pada seluruh (100\%) responden radioterapi dengan mastektomi mengalami berbagai gangguan tidur pada komponen latensi tidur $>60$ menit, durasi tidur < 5 jam, dan disfungsi pada siang hari. Pada sebagain besar responden kemoterapi dengan mastektomi, yaitu 14 dari 17 responden mengalami gangguan tidur pada komponen durasi tidur $<5$ jam. Responden dengan skor terburuk, yaitu 18 terjadi pada responden yang menjalani radioterapi dengan mastektomi (2 orang) dan responden dengan stadium stadium IV (3 orang).

Didalam ilmu keperawatan ada berbagai macam bentuk terapi nonfarmakologis adalah dengan pemberian terapi Musik dan Murottal Al-Qur 'an, yang dapat menurunkan nyeri fisiologis, dengan mengalihkan perhatian seseorang dari nyeri. Perawat dapat menggunakan musik dengan kreatif diberbagai situasi klinik. Terapi religi dapat mempercepat penyembuhan, hal ini telah dibukikan oleh berbagai ahli seperti yang telah dilakukan Ahmad al Khadi, Direktur Utama Islamic Medicine Institute for Education and Research di Florida, Amerika Serikat. Hasil penelitianya dengan tema pengaruh Al-Qur an pada manusia dalam perspektif fisiologi dan psikologi menunjukan hasil positif bahwa mendengarkan ayat suci Al-Qur'an memiliki pengaruh yang signifikan dalam menurunkan ketegangan urat saraf reflektif dan hasil ini tercatat dan terukur secara kuantitatif dan kualitatif oleh sebuah alat berbasis komputer (Potter and Perry (2006) dalam Khoiriyah (2016)).

RSUD dr. H. Abdoel Moeloek Provinsi Lampung merupakan salah satu rumah sakit umum daerah yang dijadikan rujukan untuk kasus-kasus yang tidak dapat ditangani oleh pusat-pusat pelayanan kesehatan lain termasuk kasus kanker payudara (mastektomi). Hasil observasi awal di RSUD dr. H. Abdoel Moeloek Provinsi Lampung dari bagian Rekam Medis, data kasus kanker payudara yang menjalani rawat inap pada tahun 2017 sebanyak 64 kasus dimana yang menjalani operasi mastektomi sebanyak 45 pasien, dan pada tahun 2018 sebanyak 79 kasus dimana yang menjalani operasi mastektomi sebanyak 59 pasien (Profil RSAM Provinsi Lampung, 2018).

Berdasarkan hasil prasurvey yang peneliti lakukan Di Ruang Kemoterapi RSUD dr. H. Abdoel Moeloek Provinsi Lampung yaitu terhadap 10 pasien dengan kanker payudara dengan cara wawancara, diketahui bahwa 6 pasien $(60 \%)$ mengalami gelisah pada malam hari sehingga sulit untuk tidur (insomnia), dan 4 pasien (40\%) mengatakan sering terbangun saat tidur dengan frekuensi 4-5 kali dalam semalam.

Berdasarkan latar belakang tersebut, penulis tertarik untuk melakukan penelitian tentang "Pengaruh Terapi Murottal Terhadap Kualitas Tidur Pasien Post Op Mastektomi di RSUD dr. H. Abdoel Moeloek Provinsi Lampung". 


\section{METODE PENELITIAN}

Jenis penelitian yang digunakan dalam penelitian ini adalah kuantitatif yaitu penelitian yang berlandaskan filsafat positivisme, digunakan untuk meneliti pada populasi dan sampel tertentu, pengumpulan data menggunakan instrument penelitian, analisis data bersifat kuantitatif statistik dengan tujuan untuk menguji hipotesis (Sulistyaningsih, 2016).

Dalam penelitian ini peniliti menggunakan rancangan analisis dengan menggunakan pendekatan quasi eksperimen, dapat diartikan sebagai penelitian yang mendekati eksperimen atau eksperimen semu. Bentuk penelitian ini banyak digunakan dibidang ilmu pendidikan atau penelitian lain dengan subjek yang diteliti adalah manusia, dimana mereka tidak boleh dibedakan antara satu dengan yang lain seperti mendapat perlakuan karena berstatus sebagai grup control. Pada penelitian kuasi eksperimen peneliti dapat membagi grup yang ada dengan tanpa membedakan antara control dan grup secara nyata dengan tetap mengacu pada bentuk alami yang sudah ada (Sugiyono, 2016).

Populasi dalam penelitian ini adalah semua responden yang mengalami kanker payudara dengan mastektomi pada tahun 2018 sampai dengan Maret tahun 2019 di RSUD dr. $\mathrm{H}$. Abdoel Moeloek Provinsi Lampung berjumlah 40 pasien.
HASIL PENELITIAN

Tabel 1.

Distribusi Frekuensi Usia

Responden di RSUD dr. H. Abdoel Moeloek Provinsi Lampung Tahun 2019

\begin{tabular}{ccc}
\hline Usia Ibu & Frekuensi & $\begin{array}{c}\text { Persentase } \\
(\%)\end{array}$ \\
\hline $24-29$ & 23 & 57,5 \\
$\begin{array}{c}\text { Tahun } \\
\text { 30-37 } \\
\text { Tahun }\end{array}$ & 17 & 42,5 \\
\hline Jumlah & 40 & 100,0 \\
\hline
\end{tabular}

Berdasarkan tabel 1, diketahui bahwa di RSUD dr. H. Abdoel Moeloek Provinsi Lampung Tahun 2019, sebagian besar usia responden 24-29 Tahun yang berjumlah 23 responden $(57,5 \%)$.

Tabel 2.

Distribusi Frekuensi Pendidikan Ibu di RSUD dr. H. Abdoel Moeloek Provinsi Lampung Tahun 2019

\begin{tabular}{ccc}
\hline $\begin{array}{c}\text { Pendidika } \\
\text { n Ibu }\end{array}$ & $\begin{array}{c}\text { Frekuens } \\
\mathbf{i}\end{array}$ & $\begin{array}{c}\text { Persentas } \\
\mathbf{e}(\%)\end{array}$ \\
\hline SD & 3 & 7,5 \\
\hline SMP & 13 & 32,5 \\
\hline SMA & 15 & 37,5 \\
\hline D3 & 6 & 15,0 \\
\hline S1 & 3 & 7,5 \\
\hline Jumlah & $\mathbf{4 0}$ & $\mathbf{1 0 0 , 0}$ \\
\hline
\end{tabular}

Berdasarkan tabel 2, diketahui bahwa di RSUD dr. H. Abdoel Moeloek Provinsi Lampung Tahun 2019, sebagain besar responden mempunyai riwayat pendidikan SMA yang berjumlah 15 responden $(37,5 \%)$. 
Tabel 3.

Distribusi Frekuensi Pekerjaan Responden di RSUD dr. H. Abdoel Moeloek Provinsi Lampung

Tahun 2019

\begin{tabular}{ccc}
\hline $\begin{array}{c}\text { Pekerjaan } \\
\text { Ibu }\end{array}$ & $\begin{array}{c}\text { Frekuens } \\
\mathbf{i}\end{array}$ & $\begin{array}{c}\text { Persentas } \\
\mathbf{e ~ ( \% )}\end{array}$ \\
\hline IRT & 16 & 40,0 \\
\hline Buruh & 3 & 7,5 \\
\hline Wiraswast & 8 & 20,0
\end{tabular}

\begin{tabular}{ccc}
\hline Swasta & 9 & 22,5 \\
\hline PNS & 4 & 10,0 \\
\hline Jumlah & 40 & 100,0 \\
\hline
\end{tabular}

Berdasarkan tabel 3, diketahui bahwa di RSUD dr. H. Abdoel Moeloek Provinsi Lampung Tahun 2019, sebagian besar responden mempunyai pekerjaan sebagai IRT yang berjumlah 16 responden $(40,0 \%)$.

Analisis Univariat

Tabel 4.

Rata-Rata Kualitas Tidur Pasien Post Op Mastektomi Sebelum Diberikan Terapi Murottal Al-Qur'an Di RSUD dr. H. Abdoel Moeloek Provinsi Lampung

\begin{tabular}{cccccc}
\hline $\begin{array}{c}\text { Kualitas } \\
\text { Tidur }\end{array}$ & $\mathrm{N}$ & $\begin{array}{c}\text { Nilai } \\
\text { Terendah }\end{array}$ & $\begin{array}{c}\text { Nilai } \\
\text { Tertinggi }\end{array}$ & $\begin{array}{c}\text { Rata- } \\
\text { Rata }\end{array}$ & $\begin{array}{c}\text { Standar } \\
\text { Deviasi }\end{array}$ \\
\hline Sebelum & 40 & 6 & 49 & 32,40 & 12,900 \\
\hline
\end{tabular}

Berdasarkan tabel 4.1, diketahui bahwa nilai rata-rata (mean) kualitas tidur pasien post op mastektomi sebelum diberikan terapi murottal al-qur'an di RSUD dr.
H. Abdoel Moeloek Provinsi Lampung Tahun 2019 adalah 32,40 dengan nilai terendah 6 dan nilai tertinggi 49 (standar deviasi: 12,900).

Tabel 5.

Rata-Rata Kualitas Tidur Pasien Post Op Mastektomi Sesudah Diberikan Terapi Murottal Al-Qur'an Di RSUD dr. H. Abdoel Moeloek Provinsi Lampung Tahun 2019

\begin{tabular}{cccccc}
\hline $\begin{array}{c}\text { Kualitas } \\
\text { Tidur }\end{array}$ & $\mathrm{N}$ & $\begin{array}{c}\text { Nilai } \\
\text { Terendah }\end{array}$ & $\begin{array}{c}\text { Nilai } \\
\text { Tertinggi }\end{array}$ & $\begin{array}{c}\text { Rata- } \\
\text { Rata }\end{array}$ & $\begin{array}{c}\text { Standar } \\
\text { Deviasi }\end{array}$ \\
\hline Sesudah & 40 & 5 & 32 & 21,03 & 7,506
\end{tabular}

Berdasarkan tabel 4.2, diketahui bahwa nilai rata-rata (mean) kualitas tidur pasien post op mastektomi sesudah diberikan terapi murottal alqur'an di RSUD dr. $\mathrm{H}$.
Abdoel Moeloek Provinsi Lampung Tahun 2019 adalah 21,03 dengan nilai terendah 5 dan nilai tertinggi 32 (standar deviasi: 7,506).

\section{Analisis Bivariat}

Tabel 6.

Pengaruh Terapi Murottal Al-qur'an Terhadap Kualitas Tidur Pasien Post Op Mastektomi Di RSUD dr. H. Abdoel Moeloek Provinsi Lampung

Tahun 2019 


\begin{tabular}{cccccc}
\hline Variabel & N & Mean & $\begin{array}{c}\text { Nilai } \\
\text { Selisih }\end{array}$ & SD & $\begin{array}{c}\text { P- } \\
\text { Value }\end{array}$ \\
\hline $\begin{array}{c}\text { Sebelum Diberi } \\
\begin{array}{c}\text { Terapi Murottal Al- } \\
\text { qur'an }\end{array}\end{array}$ & 40 & 32,40 & 11,37 & 12,900 & \\
\cline { 1 - 1 } $\begin{array}{c}\text { Sesudah Diberi } \\
\text { Terapi Murottal Al- } \\
\text { qur'an }\end{array}$ & & 21,03 & & 7,506 & \\
\hline
\end{tabular}

Berdasarkan table 4.3, diketahui bahwa di RSUD dr. H. Abdoel Moeloek Provinsi Lampung Tahun 2019, rata-rata kualitas tidur responden sebelum diberikan terapi murottal al-qur'an adalah 32,40 dengan standar deviasi 12,900 dan rata-rata kualitas tidur responden sesudah diberikan terapi murottal al-qur'an 21,03 dengan standar deviasi adalah 7,506, sehingga

\section{PEMBAHASAN}

\section{Univariat}

\section{a. Kualitas Tidur Sebelum Terapi Murottal Al-qur'an \\ Berdasarkan hasil penelitian,} diketahui bahwa nilai rata-rata (mean) kualitas tidur pasien post operasi mastektomi sebelum diberikan terapi murottal al-qur'an di RSUD dr. H. Abdoel Moeloek Provinsi Lampung Tahun 2019 adalah 32,40 dengan nilai terendah 6 dan nilai tertinggi 49 (standar deviasi: 12,900).

Penatalaksanaan pada pasien kanker payudara dengan stadium lanjut memiliki prognosis yang lebih buruk dibandingkan dengan kanker payudara stadium dini, bahkan tindakan operatif pun tidak dapat menyembuhkannya karena kanker sudah mengalami penyebaran ke organ-organ penting. Secara garis besar, penatalaksanaan kanker payudara dibagi menjadi dua, yaitu terapi lokal dan terapi sistemik (kemoterapi, terapi hormonal, dan penggantian sumsum tulang). Terapi lokal bertujuan untuk menyingkirkan adanya kanker local yang meliputi diketahui nilai selisih dalam penelitian ini adalah 11,37. Berdasarkan uji statistik, Uji $T$ di dapatkan $p$-value 0,000 , atau $p$ value $<0,05$ maka dapat disimpulkan bahwa terdapat pengaruh terapi murottal al-qur'an terhadap kualitas tidur pasien post op mastektomi di RSUD dr. H. Abdoel Moeloek Provinsi Lampung Tahun 2019.

bedah konservatif (lumpectomy dan terapi radiasi), mastektomi yang dimodifikasi, serta mastektomi dengan rekontruksi (Solehati \& Kosasih, 2015).

Menurut Akman et al. (2015), gangguan tidur diketahui mempengaruhi kualitas hidup dan psikologis penderita kanker. Gangguan tidur seperti nyeri dapat membangunkan seseorang dari tidur biasanya, mencegah untuk tertidur, dan berkontribusi terhadap hilangnya energi atau kelelahan. Kelelahan sendiri dapat mengakibatkan tidur pada siang hari dan terjadi interupsi tidur pada malam hari (Alifiyanti,dkk, 2017).

Ukuran dimana seseorang itu dapat kemudahan dalam memulai tidur dan untuk mempertahankan tidur, kualitas tidur seseorang dapat digambarkan dengan lama waktu tidur, dan keluhan - keluhan yang dirasakan saat tidur ataupun sehabis bangun tidur. Kebutuhan tidur yang cukup ditentukan selain oleh faktor jumlah jam tidur (kuantitas tidur), juga oleh faktor kedalaman tidur (kualitas tidur). Beberapa faktor yang mempengaruhi kuantitas dan kualitas tidur yaitu, faktor fisiologis, 
faktor psikologis, lingkungan dan gaya hidup. Dari faktor fisiologis berdampak dengan penurunan aktivitas sehari - hari, rasa lemah, lelah, daya tahan tubuh menurun, dan ketidak stabilan tanda tanda vital, sedangkan dari faktor psikologis berdampak depresi, cemas, dan sulit untuk konsentrasi (Potter dan Perry (2005) dalam Lukman (2013)).

Berdasarkan hasil penelitian yang peneliti lakukan, diketahui bahwa rata-rata kualitas tidur pada pasien post operasi mastektomi bisa dikatakan buruk, hal ini dikarenakan responden mengalami nyeri post op dan merasa cemas akan kondisi setelah operasi. Diharapkan dengan cara pemberian terapi murottal alqur'an, maka kualitas tidur responden akan lebih baik.

\section{b. Kualitas Tidur Sesudah Terapi Murottal Al-qur'an \\ Berdasarkan hasil penelitian,} diketahui bahwa nilai rata-rata (mean) kualitas tidur pada pasien post operasi mastektomi sesudah diberikan terapi murottal al-qur'an di RSUD dr. H. Abdoel Moeloek Provinsi Lampung Tahun 2019 adalah 21,03 dengan nilai terendah 5 dan nilai tertinggi 32 (standar deviasi: 7,506).

Penelitian Nanik Puji Rochmawati (2018), tentang Pengaruh Murottal Terhadap Nyeri Post Operasi di Paviliun Asoka RSUD Kabupaten Jombang Tahun 2018, menyebutkan bahwa Dari analisis bivariat diperoleh sebagian besar responden sebelum (pre test) diberikan terapi berada dalam rentang nyeri sedang 24 responden $(60,0 \%)$, hampir setengahnya responden berada dalam rentang nyeri berat 14 responden $(35,0 \%)$ dan sebagian kecil responden yang berada dalam rentang nyeri sangat berat yaitu 2 responden $(5,0 \%)$. Sedangkan setelah (post test) menunjukkan bahwa sebagian besar responden berada dalam rentang nyeri ringan 24 responden $(60,0 \%)$ dan hampir setengahnya dari responden berada dalam rentang nyeri sedang 16 responden (40,0\%). Berdasarkan hasil analisis menggunakkan salah satu program komputer yaitu SPSS 20, didapatkan hasil Uji $t$ sampel berpasangan adalah 0,000 hal ini menunjukkan bahwa nilai $p<0,05$ maka $\mathrm{H}_{1}$ diterima dan $\mathrm{H}_{0}$ di tolak atau dengan kata lain ada pengaruh murottal qur"an terhadap nyeri post operasi di Paviliun Asoka RSUD Jombang tahun 2018.

Berdasarkan hasil penelitian yang peneliti lakukan, diketahui bahwa setelah diberikan terapi murottal, rata-rata sebagian besar responden mempunyai kualitas tidur yang baik, hal ini dikarenakan adanya pengaruh yang besar terapi murottal al-qur'an terhadap penurunan tingkat nyeri dan menurunkan kecemasan pasien sehingga kualitas tidur pada pasien post operasi mastektomi meningkat. Dengan dilakukan terapi murottal alqur'an maka kualitas tidur responden menjadi meningkat lebih baik.

\section{Bivariat}

\section{a. Pengaruh Terapi Murottal} terhadap Kualitas Tidur Pasien Post Op Mastektomi

Berdasarkan hasil penelitian, diketahui bahwa di RSUD dr. $\mathrm{H}$. Abdoel Moeloek Provinsi Lampung Tahun 2019, rata-rata kualitas tidur sebelum diberikan terapi murottal adalah 32,40 dengan standar deviasi 12,900 dan rata-rata kualitas tidur responden sesudah diberikan terapi murottal adalah 21,03 dengan standar deviasi adalah 7,506, sehingga diketahui nilai selisih dalam penelitian ini adalah 11,37. Berdasarkan uji statistik, Uji $T$ di 
dapatkan $p$-value 0,000, atau $p$ value $<0,05$ maka dapat disimpulkan bahwa terdapat pengaruh terapi murottal al-qur'an terhadap kualitas tidur pasien post operasi mastektomi di RSUD dr. H. Abdoel Moeloek Provinsi Lampung Tahun 2019.

Penelitian ini sesuai dengan teori menurut Suryana (2012), dimana terapi murottal dapat menurunkan hormone hormon stres, mengaktifkan hormon endofrin alami, meningkatkan perasaan rileks dan mengalihkan perhatian dari rasa takut, cemas dan tegang, memperbaiki sistem kimia tubuh sehingga menurunkan tekanan darah serta memperlambat pernafasan, detak jantung, denyut nadi dan aktivitas gelombang otak.

Faktor-faktor

yang

berhubungan dengan gangguan pemenuhan kebutuhan tidur pasien post operasi diantaranya (Sutanto, dkk, 2017).

a. Penyakit

Orang yang sakit membutuhkan lebih banyak tidur dari pada normal, dan irama normal tidur dan terjaga seringkali terganggu. Orang yang kehilangan tidur REM mengakibatkan waktu tidur lebih banyak dari normal.

b. Nyeri

Nyeri pasca operasi muncul disebabkan oleh rangsangan mekanik luka yang menyebabkan tubuh menghasilkan mediatormediator kimia nyeri. Intesitas bervariasi mulai dari nyeri ringan sampai nyeri berat namun menurun sejalan dengan proses penyembuhan.

c. Kelelahan

Diketahui bahwa seseorang yang mengalami kelelahan sedang biasanya dapat tidur dengan tenang/nyenyak. Kelelahan dapat juga mempengaruhi pola tidur seseorang. Orang yang menglami kelelahan berlebihan memperpendek periode pertama tidur paradoksikal (REM). Pada orang yang istirahat, periode REM menjadi panjang/lama.

d. Kecemasan dan Emosi

Kecemasan dan depresi seringkali menganggu tidur. Orang yang dipenuhi dengan problem pribadi mungkin tidak mampu untuk relak dengan cukup yang dapat membawanya menjadi tidur. Kecemasan meningkatkan kadar norepinephrin di dalam darah melalui stimulasi sistem saraf simpatis. Zat kimia ini mengakibatkan perubahan pada berkurangnya tidur tahap IV NREM dan tidur REM serta terbangun.

e. Alkohol dan Stimulant

Orang yang meminum berlebihan alkohol seringkali mengalami gangguan tidur. Alkohol yang berlebihan mengganggu tidur REM, diperkirakan dapat mempercepat onset tidur. Dapat juga menyebabkan mimipi buruk. Toleransi terhadap alkohol juga mempengaruhi tidur. Orang yang mentoleransi alkohol mungkin tidak dapat tidur dengan baik dan menjadi iritabel. Minuman yang mengandung caffein berperan sebagai stimulant terhadap sistem saraf pusat, sehingga mengganggu tidur.

f. Kenyamanan Ruang Perawatan Lingkungan fisik tempat seseorang tidur sangat berpengaruh penting pada kemampuan untuk tertidur dan tetap tertidur. Kondisi tempat tidur yang kurang nyaman, ventilasi yang tidak esensial, suara ribut dari teman sekamar, pintu kamar yang sering dibuka dan ditutup, bunyi langkah kaki, bunyi telepon, dan pencahayaan yang tidak sesuai dengan tempat tidur, serta suhu ruangan yang terlalu hangat dapat 
mempengaruhi kebutuhan tidur pasien dan memperpanjang proses pemulihan individu yang sakit.

g. Motivasi

Motivasi juga mempengaruhi tidur, dengan adanya keinginan untuk tetap bangun dan waspada menahan kantuk dapat menimbulkan gangguan proses tidur. Motivasi merupakan dorongan dan usaha untuk memenuhi suatu kebutuhan untuk mencapai suatu tujuan. Klien sering mengalami peningkatan jumlah waktu bangun sehingga berkurangnya total waktu tidur yang mempengaruhi keinginannya untuk sembuh dari sakit.

Hasil penelitian ini sejalan dengan penlitian yang dilakukan Nurliana Khoiriyah (2016), tentang Pemberian Terapi Murottal AlQur'an Terhadap Waktu Pulih Sadar Pada Pasien Dengan Tumor Mammae Dextra Dengan Anestesi General Di Ruang Mawar A12 RSUD dr Soediran Mangun Soemarso Wonogiri Tahun 2016, menyebutkan bahwa Hasil pemberian terapi murottal Al- Quran surah Ar- Rahman terhadap waktu pulih sadar pasien lebih cepat pada menit ke- 45 dan di ukur menggunakan alat ukur Alderetescore dengan nilai 8 , serta pemberian terapi murotta Al- Quran surah Ar- Rahman lebih efektif pada pasien dengan kecemasan saat sebelum dilakukan operasi dan belum dilakukan terapi di dapatkan nilai dari HRS- A dengan hasil 48 (kecemasan berat) setelah dilakukan terapi didapatkan hasil 20 (kecemasan ringan). Menunjukan bahwa aplikasi pemberian terapi murottal Al- Quran surah Ar- Rahman dapat mempercepat waktu pulih sadar pasien serta dapat menurunkan kecemasan.
Penelitian yang dilakukan Devita Alifiyanti,dkk (2017), tentang kualitas tidur pasien kanker payudara berdasarkan terapi yang diberikan di RSUP Dr. Hasan Sadikin Bandung didapatkan hasil pada jenis terapi pengobatan kanker payudara yang dijalani oleh responden, bahwa semua terapi pengobatan kanker menyebabkan kualitas tidur yang buruk. Pada sebagian besar responden dengan single mastektomi, yaitu 5 dari 11 responden mengalami gangguan tidur pada komponen latensi $>60$ menit. Pada seluruh (100\%) responden radioterapi dengan mastektomi mengalami berbagai gangguan tidur pada komponen latensi tidur $>60$ menit, durasi tidur < 5 jam, dan disfungsi pada siang hari. Pada sebagain besar responden kemoterapi dengan mastektomi, yaitu 14 dari 17 responden mengalami gangguan tidur pada komponen durasi tidur $<5$ jam. Responden dengan skor terburuk, yaitu 18 terjadi pada responden yang menjalani radioterapi dengan mastektomi (2 orang) dan responden dengan stadium stadium IV (3 orang).

Berdasarkan hasil penelitian yang peneliti lakukan, diketahui bahwasanya terapi murottal alqur'an memberikan pengaruh yang besar terhadap peningkatan kualitas tidur pada pasien post operasi mastektomi dengan dibuktikannya nilai selisih yang baik yaitu 11,37, namun ada sebagian responden yang telah diberikan terapi murottal, namun kualitas tidurnya masih buruk, hal ini dikarenakan kurangnya motivasi ingin pulih dan beranggapan bahwasanya penyakit kanker tidak dapat disembuhkan, faktor kelelahan setelah post operasi, sehingga responden kurang menghayati bacaan murottal alqur'an. 


\section{KESIMPULAN}

a. Diketahui bahwa di RSUD dr. H. Abdoel Moeloek Provinsi Lampung Tahun 2019, sebagian besar usia responden $24-29$ yang berjumlah 23 responden (57,5\%), riwayat pendidikan SMA yang berjumlah 15 responden $(37,5 \%)$, pekerjaan sebagai IRT yang berjumlah 16 responden $(40,0 \%)$.

b. Diketahui bahwa nilai rata-rata (mean) kualitas tidur pasien post operasi mastektomi sebelum diberikan terapi murottal alqur'an di RSUD dr. H. Abdoel Moeloek Provinsi Lampung Tahun 2019 adalah 32,40 dengan nilai terendah 6 dan nilai tertinggi 49 (standar deviasi: 12,900).

c. Diketahui bahwa nilai rata-rata (mean) kualitas tidur pasien post operasi mastektomi sesudah diberikan terapi murottal alqur'an di RSUD dr. H. Abdoel Moeloek Provinsi Lampung Tahun 2019 adalah 21,03 dengan nilai terendah 5 dan nilai tertinggi 32 (standar deviasi: 7,506).

d. Berdasarkan uji statistik, Uji T di dapatkan $p$-value 0,000, atau $p$ value < 0,05 maka dapat disimpulkan bahwa terdapat pengaruh terapi murottal terhadap kualitas tidur pasien post operasi mastektomi di RSUD dr. H. Abdoel Moeloek Provinsi Lampung Tahun 2019.

\section{SARAN}

Berdasarkan hasil kesimpulan diatas, maka saran yang harus diperhatikan adalah sebagai berikut:

a. Diharapkan dengan hasil penelitian ini responden dapat menerapkan terapi murottal Alqur'an dirumah, sehingga dengan terapi murottal maka kualitas tidur pasien post op dapat teratasi dengan baik.

b. Diharapkan hasil penelitian ini dapat dijadikan sebagai salah satu intervensi oleh tenaga kesehatan untuk meningkatkan kualitas tidur pada pasien post op.

c. Diharapkan untuk peneliti selanjutnya agar dapat melakukan penelitian lebih lanjut tentang pengaruh terapi relaksasi terhadap dengan kualitas tidur pasien post operasi.

\section{DAFTAR PUSTAKA}

APJI. (2017). Data Statistik Pengguna Internet Indonesia Tahun 2016.

https://apjii.or.id/downfile Ifile/BULETINAPJIIEDISIO5No vember2016.pdf

Aryanti, W. (2015). Faktor-Faktor Yang Mempengaruhi Optimisme Kesembuhan Pada Pasien Kanker Payudara.

Delima, R., Arianti, N. K., \& Pramudyawardani, B. (2015). Identifikasi Kebutuhan Pengguna Untuk Aplikasi Permainan Edukasi Bagi Anak Usia 4 sampai 6 Tahun. Jurnal Teknik Informatika dan Sistem Informasi, 1 (1), 42.

Ernawati. (2015). Pengaruh Penggunaan Gadget Terhadap Penurunan Tajam Penglihatan Pada Anak Usia Sekolah (6-12 Tahun).

Gunawan. (2017). Hubungan Durasi Penggunaan Gadget terhadap Perkembangan Sosial Anak Prasekolah di TK PGRI 33 Sumurboto. Banyumanik.

Ilyas S, Yulianti, S.R. (2014). Ilmu Penyakit Mata, edisi 5. Jakarta: Badan Penerbit. FKUI.

Indrarini, (2016). Gambaran Miopi Pada Anak Sekolah Dasar Di Daerah Rural Dan Urban (Studi kasus Kecamatan Sumowono Kabupaten Semarang dan Kecamatan 
Semarang Selatan Kota Semarang) Volume 4, Nomor 4, Oktober 2016 (ISSN: 23563346) hhtp://ejournalsl.undip.ac.id/index.php/jk $\underline{m}$

Iswidharmanjaya. (2014). Bila si kecil bermain gadget. Panduan bagi orang tua untk memahani faktor. Bogor: Bisa Kimia.

Jati., Herawati. (2014). Segmentasi Mahasiswa Program Studi Ilmu Komunikasi UAJY dalam Menggunakan Gadget. Diakses tanggal 1 juni 2016 dari http://ejournal.UAJY.ac.id> jurnal

Manumpil. (2015). Hubungan Penggunaan Gadget Dengan Tingkat Prestasi Siswwa Di SMA Negeri 9 Manado ejournal Keperwatan (e-Kep) Volume 3 Nomor 2. April 2015 https://media.neliti.com/m edia/publications/112721ID-hubungan -penggunaangadget-dengan-tingka.pdf.

Nithy. (2018). Survey tentang Smarthphone \& Tablet Hasilnya mengejutkan. https://id.theasianparent.co $\underline{m}$

Notoatmodjo. (2010). Metodelogi Penelitian Kesehatan. Jakarta: PT. Rineka Cipta.

Nourmayanti. D. (2014). FaktorFaktor yang Berhubungan dengan Keluhan Kelelahan Mata Pada Pekerja Pengguna Komputer Di Corporate Customer Care Center (C4) PT. Telekomunikasi Indonesia Tangerang. Jakarta: UIN Syarif Hidayatullah.

Ratanna (2014). Kelainan Refraksi Pada Anak di BLU RSU Prof. Dr. R.D.Kandau Jurnal e-Clinic (eCL), Volume 2, Nomor 2, Juli 2014.

Download.portalgaruda.org/a rticle.php?.
Riskesdas (2013). Riset Kesehatan Dasar, RISKESDAS. Jakarta: Balitbang Kemenkes RI.

Rudhiati. (2015). Hubungan Durasi Bermain Video Game Dengan Ketajaman Penglihatan Anak Usia Sekolah.

Rudhiati., Apriany., Hardianti. (2015). Hubungan Durasi Bermain Video Game dengan Ketajaman Penglihatan Anak Usia Sekolah. Jurnal Skolastik Keperawatan.

Sari. T. P., Mitsalia, A.A. (2016). Pengaruh Penggunaan Gadget Terhadap Personal Sosial Anak Usia Pra Sekolah Di TKit Al Mukmin. Profesi (online), Vol.13, No.2, dalam (http://ejournal.stikespku.a c,id diakses 12 Februari 2019)

Sugiyono. (2016). Metode Penelitian Kuantitatif, Kualitatif dan R\&D. Bandung: PT. Alfabet

Trinika, Y., A. Nurfianti., dan A. Irsan. (2015). Pengaruh Penggunaan Gadget Terhadap Perkembangan Psikososial Anak Usia Prasekolah (3-6 tahun) di TK Swasta Kristen Immanuel Tahun Ajaran 2014-2015. Universitas Tanjungpura. Pontianak.

Widiawati, I., Sugiman, H., \& Edy. (2014). Pengaruh Penggunaan Gadget Terhadap Daya Kembang Anak. Jakarta: Universitas Budi Luhur. E-journal Keperawatan, 6, 1-6.

Wijanarko. (2016). Ayah Ibu Baik. Parenting Era Digital. Pengaruh Gadget Pada Perilaku Dan Kemampuan Anak Menjadi Orang Tua Bijak Di Era Digital. Jakarta. Keluarga Bahagia Indonesia. 